Article

\title{
Research on Green Productivity of Chinese Real Estate Companies-Based on SBM-DEA and TOBIT Models
}

\author{
Zhao Yang and Hong Fang * \\ School of Economics \& Management, Beihang University, Beijing 100191, China; YangZhaoY@buaa.edu.cn \\ * Correspondence: fanghong@buaa.edu.cn; Tel.: +86-185-1361-5576
}

Received: 14 March 2020; Accepted: 8 April 2020; Published: 13 April 2020

check for updates

\begin{abstract}
Apart from promoting social-economic development and increasing social employment, the real estate industry in China has also brought up problems such as high energy consumption and high emissions. Scholars now focus more on energy conservation, emission reduction and sustainable development of real estate companies in their current research. The data used by this paper are three-year panel data from 2015 to 2018, with observations from 15 representative real estate companies. $\mathrm{CO}_{2}$ and green credit index are introduced as the undesirable output and the green output of real estate companies respectively. First, with the DEA model and the Malmquist index model, this paper evaluates the green productivity of real estate companies statically and dynamically. The Tobit model is then employed by the author to analyze factors that may affect green productivity. Our results indicate that (1) the green productivities of 15 Chinese real estate companies have improved by various degrees. The average green productivity rises from $0.701 \mathrm{in}$ 2015 to 0.849 in 2018, indicating that the energy utilization rate of enterprises has gradually increased. From the calculation and decomposition of the Malmquist total factor productivity index, we know that technological progress is vital in improving the green productivity of real estate companies. (2) As for the influencing factors, the green productivity is positively related to factors such as policy compliance indicator $\mathrm{P}$, environmental responsibility commitment indicator $\mathrm{R}$, indicator of green innovation capability I, and indicator of green development information disclosure M. The asset-liability ratio on the contrary has a negative impact on green productivity. It's worth to point out that the green innovation index and green productivity is significantly correlated and the correlation coefficient can be up to 0.636 , which implies that the key to improving green productivity is to increase research and development investment.
\end{abstract}

Keywords: real estate companies; SBM-DEA; green credit index; green productivity; tobit regression

\section{Introduction}

In recent years, due to the impact of greenhouse gases, especially the impact of $\mathrm{CO}_{2}$ emissions, global warming and climate change have become increasingly serious, which has attracted the attention of many countries in the world. The problem of excessive $\mathrm{CO}_{2}$ emissions is unanimously considered as an important obstacle to the sustainable development of society. The report issued by the Intergovernmental Panel on Climate Change (IPCC) predicts that the world temperature will rise by $1.1-6.4{ }^{\circ} \mathrm{C}$ [1], which will greatly threaten the survival of human beings and other species. It is gratifying that many countries have realized the necessity of energy conservation and emission reduction, and signed the Paris agreement at the 2015 climate change conference in Paris, striving to control the global average temperature rise in this century to within $2{ }^{\circ} \mathrm{C}$, through cooperation [2].

The real estate industry is one of the pillar industries in our national economy. It plays an important role in promoting industrialization and urbanization, improving the living standards of 
residents and driving the economic growth of China. Its rapid development has promoted the growth of the national economy and its contribution to GDP has continued to increase. The contribution rate has risen from $11.4 \%$ in 2001 to $26.0 \%$ in 2016; approximately 51.8 million people were engaged in the real estate industry in China in 2016 [3]. However, the booming development of the real estate industry also results in serious problems in regard to energy consumption and environment pollution. Since 2008, the carbon dioxide emissions in China have ranked first in the world [4], of which the carbon emissions of the real estate industry account for a relatively high proportion, and this ratio is still increasing. In 2011, the carbon emissions of the real estate industry accounted for $28 \%$ of the total national emissions; in 2016, this number has grown to be $43.7 \%$ [3]. The growing carbon emissions of the real estate industry have become a major barrier in reducing the emissions of greenhouse gases. The real estate industry has been driven into a trend of green and sustainable development.

Green real estate is an industry developed under the condition of resources conservation, environment protection and harmony realization between human and nature. The star level and area of green building are important indicators to measure the green development of green real estate, but compared with green building, the concept of green real estate covers a wider range of activities, such as project planning, construction, operation, management, maintenance, decoration and service etc., and emphasizes all green related links in the whole construction project cycle. From the ecological civilization of the 12th Five-Year Plan, to the green development blueprint of the 13th Five-Year Plan, the Chinese government pays more attention to the greenness of economic and social development, which provides a good opportunity to develop the green real estate industry. The government has issued mandatory policies and economic policies to promote the green development of real estate enterprises. When the Green Building Evaluation Standard 'GB/t50378-2006' was issued in 2006, China's green real estate industry began to officially start. The 12th Five-Year Plan for the development of green buildings and green ecological urban areas and the 13th Five-Year Plan for the development of the construction industry have played an important role in promoting the development of green buildings. The Ministry of Housing and Urban-Rural Development issued the 2019 version of the Green Building Evaluation Standard 'GB/t50378-2019', which also guided the implementation of green technology and promoted the green building to obtain operation marks. In order to better promote the green development of real estate enterprises, the Chinese government has also adopted a series of economic preferential policies to encourage real estate enterprises to invest in the construction of green buildings. In 2012, the Ministry of Finance and the Ministry of Housing and Urban-Rural Development jointly issued the implementation opinions on accelerating the development of green buildings in China. In the opinion, it is proposed to reward the green building projects constructed by enterprises according to the building area, and reward RMB 45 and RMB 80 for each square meter of two-star and three-star green building projects, respectively. In September 2018, the green financial standards working group of the national financial Standardization Technical Committee deliberated and passed the articles of association of the green financial standards working group, and promoted the development of green real estate projects by providing financial support for green real estate projects.

Green real estate has developed in China for more than ten years, and its development mode has gradually changed from policy driven to market choice. Driven by the mandatory policies and economic policies announced by relevant departments, China's green real estate industry will usher in a rapid development trend. From the current development situation, the green real estate industry is developing in a multi-level, all-round, comprehensive and effective way, under the coordination of multiple departments.

This paper calculates the green production efficiency and dynamic change of the green real estate industry in China, analyzes the factors that may affect the production efficiency of enterprises, and provides some suggestions for the sustainable development of green real estate enterprises. 


\section{Literature Review}

The research on productivity has changed from the single factor stage to the total factor stage. Before World War II, the study of industry efficiency was based on single factor productivity. In 1926, the US Bureau of Labor Statistics calculated the productivity of a company-the amount of output per person per unit of time. At this time, the productivity was still the single factor productivity. In 1954, Xilang Davis first came up with the connotation of the total factor productivity in his book Productivity Accounting; he explained the connotation of total factor productivity in detail, and proposed that all input and output factors should be taken into account when calculating productivity [5]. After the 1950s, the famous American economists Solow and Denison gradually expanded their research focus from single factor productivity to total factor productivity [6,7]. Later, research focusing on total factor productivity started to be conducted in various industries. There are many different research methods for the evaluation of production efficiency [8-12]. Data envelopment analysis (DEA) is widely used in the measurement of production efficiency, because it does not need to estimate the parameters by building production function [13-16].

As for the total factor productivity in the field of the real estate construction industry, most scholars tend to conduct their research from the industry (region) and enterprise levels. Earlier studies on the productivity of the real estate industry mostly focus on the evaluation of economic efficiency. After analyzing the statistical data of the real estate industry in various provinces and cities in China, some scholars found that the comprehensive technical efficiency (CTE) of the real estate industry in these provinces and cities was low, and the overall development trend of CTE was downward; they therefore proposed that the effective way to improve the technology efficiency of the real estate industry is to promote the marketization and strengthen the management of investment and financing of the real estate industry [17-19]. From a regional perspective, Zhao and Zheng made a comprehensive comparison on the efficiency of Chinese real estate companies and their total factor productivity (TFP); their results indicated that the overall productivity of Chinese real estate companies is very low, due to the irrational industrial structure and the diseconomies of scale; the value of productivity varies from region to region and the productivity of western real estate companies is significantly lower compared to the productivity of eastern and central real estate companies [20,21]. At the micro level, some scholars evaluated the productivity of real estate companies in Europe and the US; they found that the productivity gap among different companies was relatively obvious, but labor input and cultural quality of labor had no significant influence on the productivity of these companies; technology productivity is closely related to economic efficiency [22,23]. Some scholars evaluated the productivity of Chinese real estate companies with the DEA method; they pointed out that although Chinese real estate companies have high overall productivity, they generally have the problem of low resource utilization [24-28].

As the high pollution and high energy consumption in the real estate construction industry becomes more serious, people realize that it is necessary to investigate the energy consumption and carbon emissions of the real estate industry, while paying attention to its economic development. The green total factor productivity therefore comes forth, of which the connotation is to bring the indicators reflecting the resources and environmental factors into the calculation framework, to obtain the production efficiency considering the ecological factors. In recent years, research on GTFP has focused on GTFP measurement and its influencing factors. Taking undesirable output into consideration, Pittman (1983) was the first researcher who calculated GTFP with data envelopment analysis (DEA) [29]. Extending the research of Pittman, Chung (1997) and Fare (2001) formed a directional distance function and proposed a ML (Malmquist-Luenberger) index which was more in line with environmental concepts [30,31]. However, most of these studies are limited to radial and orientation methods, which cannot effectively overcome the measurement deviation caused by radial or orientation selection. Hence, a more general and highly favored SBM directional distance function was proposed by Tone (2001), on the basis of previous research [32]. In the research of green total factor productivity of the real estate construction industry, scholars mostly study from energy efficiency and $\mathrm{CO}_{2}$ emissions [33-38]. 
With the publication of the Green Building Evaluation Standard 'GB/T 50378-2006', the green real estate industry began to rise. Current research on the green real estate industry mainly exists in the following aspects: (1) Application of green materials and technology in the project [39-41]. (2) Performance evaluation of green building [42-45]. (3) Profit and cost analysis of green construction projects [46-49]. (4) Analysis of the factors driving the development of green construction projects [50-52].

In summary, some scholars have studied the production efficiency of real estate enterprises, but the evaluation indicators of these studies do not include green building area, green credit index and other indicators strongly related to the green development of real estate, and there is limited research targeted especially on the efficiency of green real estate enterprises. The research on green real estate enterprises is mostly limited to the functional evaluation and the application of green building materials, but there are few research studies on the calculation of green real estate production efficiency, the trend of efficiency dynamic change and the factors affecting the green development of enterprises. In order to make up for these shortcomings, the $\mathrm{CO}_{2}$ emissions and the green credit index published by the China Building Energy Efficiency Association are introduced as undesirable output and green output respectively in this paper; the author first evaluates the static and dynamic green production efficiency of Chinese green real estate companies with the DEA model and the Malmquist model; the Tobit regression is then used to analyze factors that might affect the green production efficiency. This paper endeavors to put forward suggestions and policy implications on improving the ecological environment of Chinese real estate.

Compared with the existing literature, the contributions of this paper are: (1) This paper not only uses the relevant economic data as the expected output and $\mathrm{CO}_{2}$ as the unexpected output, but also innovatively introduces the green credit index published by China Building Energy Conservation Association as the green output for calculation, so as to make the evaluation index more comprehensive and reflect the achievements of green development. (2) Using data from Chinese real estate companies, this paper evaluates the green total factor production efficiency of the Chinese real estate industry at the micro level; the roughness of macro-level evaluation is avoided and the results are more instructive.

\section{Materials and Methods}

\subsection{Static Efficiency Evaluation Model}

Data envelopment analysis (DEA) is an interdisciplinary research area of many disciplines, such as operations research, computer science, management and many other disciplines. A specific DEA model and method were introduced by Charnes, Cooper and Rhodes in 1978 [53]. The principle of the DEA model is that it is a data envelope which is conducted with the input and output data, to determine whether the decision-making unit (DMU) is on the data envelope surface. When the DMU falls on a relatively effective production frontier, its value is 1 and it indicates that this decision unit is valid; when the DMU fails to fall on the production frontier, the DEA is invalid.

\subsection{SBM-DEA Model with Undesirable Outputs}

The most basic models in the data envelope analysis are the CCR model (DEA model under constant returns to scale) and the BCC model (DEA model under variable returns to scale). However, one disadvantage of these two models is that they have no consideration of undesirable output. In evaluating the real estate companies' productivity, considering only the expected outputs such as the desired profit and missing the undesirable outputs such as wastewater, residue and $\mathrm{CO}_{2}$, will result in a biased estimated efficiency value. The operating conditions of these companies in this context cannot be reasonably evaluated.

In order to evaluate the influence of undesirable output on the productivity of real estate companies, this paper employed the Slacks-Based Measure of Efficiency in Data Envelopment Analysis (SBM-DEA)proposed by Tone [32]. The SBM-DEA model is superior to the traditional DEA model in introducing the slack variable into the objective function. It makes it possible for one to evaluate the 
economic efficiency when there is undesirable output and it also solves the problem of the slackness of input and output. The result of the SBM-DEA model is the green productivity of companies.

$$
\beta_{0}^{*}=\min \frac{1-\frac{1}{m} \sum_{i=1}^{m} \frac{s_{i 0}^{-}}{x_{i 0}}}{1+\frac{1}{s_{1}+s_{2}}\left(\sum_{r=1}^{s_{1}} \frac{s_{r 0}^{y}}{y_{r 0}}+\sum_{r=1}^{s_{2}} \frac{s_{r 0}^{d}}{d_{r 0}}\right)}
$$

$$
\begin{gathered}
\text { ST. } \\
x_{0}=X \lambda+s_{0}^{-} \\
y_{0}=Y \lambda-s_{0}^{y} \\
d_{0}=D \lambda+s_{0}^{d} \\
s_{0}^{-} \geq 0, s_{0}^{y} \geq 0, s_{0}^{d} \geq 0, \lambda \geq 0
\end{gathered}
$$

where: $\beta_{0}^{*}$ indicates the resource and environmental efficiency, $0 \leq \beta_{0}^{*} \leq 1$, is its value range with larger value representing higher efficiency. Matrices $X, Y$, and $D$ represent $m$ inputs, $s_{1}$ desirable outputs, and $s_{2}$ undesirable outputs of $n$ DMUs, respectively. Vectors $s_{0}^{-}$and $s_{0}^{d}$ represent the excess value of input and undesired output respectively; vector $s_{0}^{y}$ represents the insufficient value of expected output. The subscript 0 indicates the DMU being estimated. When $\beta_{0}^{*}=1$ satisfies all $s_{0}^{-}=0 s_{0}^{y}=0$ and $s_{0}^{d}=0$, the input and output of this decision unit are absolutely efficient. $s$ is slack variable of input and output; $\lambda$ is weight vector.

\subsection{Dynamic Efficiency Evaluation Model}

This paper uses the Malmquist productivity index (MPI) to catch the dynamic productivity trend of real estate companies. The Malmquist total factor productivity (TFP) can be expressed as:

$$
M_{0}\left(x_{t}, y_{t}, x_{t+1}, y_{t+1}\right)=\left[\frac{D_{0}^{t+1}\left(x_{t+1}, y_{t+1}\right)}{D_{0}^{t+1}\left(x_{t}, y_{t}\right)} \times \frac{D_{0}^{t}\left(x_{t+1}, y_{t+1}\right)}{D_{0}^{t}\left(x_{t}, y_{t}\right)}\right]^{\frac{1}{2}}
$$

$D_{0}^{t}\left(x_{t}, y_{t}\right)$ indicates the distance function in the period $t$ with reference of the current technology, $D_{0}^{t+1}\left(x_{t+1}, y_{t+1}\right)$ indicates the distance function in the period $(t+1)$ taking the current technology as reference; $D_{0}^{t}\left(x_{t+1}, y_{t+1}\right)$ and $D_{0}^{t+1}\left(x_{t}, y_{t}\right)$ represent producer input difference in comparison of the production front in the mixing period [54].

Total factor productivity can be divided into technical efficiency (EFF) and technical progress (TECH). EFF can be future split into pure technical efficiency (PE) and scale efficiency (SE). Hence, the equation of total factor productivity can be rewritten as:

$$
M_{0}\left(x_{t}, y_{t}, x_{t+1}, y_{t+1}\right)=\frac{S_{0}^{t}\left(x_{t}, y_{t}\right)}{S_{0}^{t}\left(x_{t+1}, y_{t+1}\right)} \times \frac{D_{0}^{t}\left(x_{t+1}, y_{t+1}\right)}{D_{0}^{t}\left(x_{t}, y_{t}\right)} \times\left[\frac{D_{0}^{t}\left(x_{t+1}, y_{t+1}\right)}{D_{0}^{t+1}\left(x_{t+1}, y_{t+1}\right)} \times \frac{D_{0}^{t}\left(x_{t}, y_{t}\right)}{D_{0}^{t+1}\left(x_{t}, y_{t}\right)}\right]^{\frac{1}{2}}
$$

$\frac{S_{0}^{t}\left(x_{t}, y_{t}\right)}{S_{0}^{t}\left(x_{t+1}, y_{t+1}\right)}$ represents the variation of scale efficiency, $\frac{D_{0}^{t}\left(x_{t+1}, y_{t+1}\right)}{D_{0}^{t}\left(x_{t}, y_{t}\right)}$ represents the variation of pure technological efficiency, the multiplication of these two items indicates the change of technological efficiency, $\left[\frac{D_{0}^{t}\left(x_{t+1}, y_{t+1}\right)}{D_{0}^{t+1}\left(x_{t+1}, y_{t+1}\right)} \times \frac{D_{0}^{t}\left(x_{t}, y_{t}\right)}{D_{0}^{t+1}\left(x_{t}, y_{t}\right)}\right]^{\frac{1}{2}}$ represents the variation of technological progress, and the multiplication of these three items is the total factor productivity index [55].

The total factor productivity index is greater than one when there is improvement of the general productivity, otherwise the index is less than 1 ; the estimated technological progress index is bigger than one when an enterprise's technology is advanced, otherwise it is less than one. The enlargement of an enterprise's input scale leads to a bigger-than-one scale efficiency, however, if the scale efficiency is less than one, it means that the change in the input scale leads to a decrease in efficiency; when the 
efficiency of resources relocating and using of a company is improved, the pure technology efficiency is bigger than one; a less-than-one pure technology efficiency indicates that the resource allocation lacks efficiency.

\subsection{Tobit Regression Model}

This paper adopts the Tobit regression model proposed by Tobin in 1958 to estimate the influencing factors of the efficiency of real estate companies [56]. The equation of the Tobit model is as follows:

$$
Y_{i}^{*}=\left\{\begin{array}{c}
\alpha+\beta X_{i}+\varepsilon \quad Y_{i}^{*} \leq 0 \\
0 \quad Y_{i}^{*} \leq 0
\end{array}\right.
$$

where $X_{i}$ is the independent variable vector, $\alpha$ is the intercept term vector, $\beta$ is the correlation coefficient vector, $Y_{i}$ is the observed dependent variable, and $\varepsilon$ is the random error term. In this paper, the dependent variable is the efficiency value of real estate companies, which is estimated from the CCR and SBM models. Some influencing factors are selected as independent variables. After Tobit regression is performed, the results are analyzed to determine the influence direction and intensity of the independent variables on various efficiency values.

\section{Empirical Results and Analysis}

\subsection{Variable Selection and Data Description}

Fifteen real estate companies are chosen as the sample of this paper because of the following reasons. These enterprises are recognized as green real estate operation model enterprises in the top 30 report of China green real estate index 2019, released by the China Building Energy Conservation Association. They generally adopt the green development mode, and have made certain achievements in energy conservation and emission reduction, energy use efficiency improvement, etc., which has led real estate enterprises to embark on the development path of continuous improvement of ecological environment.

The input indicators chosen by this paper are: Total Assets, Number of Employees, Number of Patents. The three output indicators are: Operating Income, Net Income, Green Credit Index, $\mathrm{CO}_{2}$ Emission. The total assets, operating income, number of employees and net income are from BVD database and annual report of the enterprise; the number of patents are from the State Intellectual Property Office. The green credit index is from the 2015-2018 China green real estate development report published by the China Building Energy Conservation Association; the calculation of this index is as follows: Green Index = the construction area with two-star logo of green building $* 30 \%+$ the construction area with three-star logo of green building* $50 \%$ (unit: 10 thousand square meters) + online voting (10 votes create one unit) * $5 \%+$ score of Jury * $15 \%$. Most of the $\mathrm{CO}_{2}$ emissions of enterprises come from the data directly published in the annual report and corporate social responsibility report. Only two enterprises, Merchants Shekou and YUEXIU PROPERTY, have not published their specific $\mathrm{CO}_{2}$ emissions; for those with unknown $\mathrm{CO}_{2}$ emissions, the author calculates their $\mathrm{CO}_{2}$ emission with the calculation method from ICPP Guidelines for National Greenhouse Gas Inventories, published by Intergovernmental Panel on Climate Change (IPCC) in 2006. The equation is as follows:

$$
\mathrm{CO}_{2}=\sum_{i=1}^{n} E i * N C V i * C E F i * C O F i *(44 / 12)
$$

Among which, $E i$ is the consumption of the $i$-th energy, NCVi is the low calorific value of the $i$-th energy, CEF $i$ is the carbon emission factor, COFi is the carbon oxidation rate, and 44/12 is the carbon conversion coefficient. All values of these factors can be obtained from General Principles for Calculation of Total Production Energy Consumption and IPCC Guidelines for National Greenhouse Gas Inventories. The consumption of various energies of a company can be acquired from the Corporate Social Responsibility Report and Company Annual Report. 
In summary, this paper uses the indicators shown in Table 1 to study the eco-environmental efficiency of the sample from 2013 to 2015.

Table 1. Input and Output Indicators of Real Estate Companies.

\begin{tabular}{cccc}
\hline Input & Expected Output & Green Output & Undesirable Output \\
\hline $\begin{array}{c}\text { Total Assets } \\
\text { (tens of thousands) }\end{array}$ & $\begin{array}{c}\text { Total Income } \\
\text { (tens of thousands) } \\
\text { Net Income } \\
\text { Number of Patent }\end{array}$ & Green Credit Index & $\mathrm{CO}_{2}$ Emission (ton) \\
Number of Employee & Return on Total Assets (\%) & & \\
\hline
\end{tabular}

\subsection{Result Analysis of DEA Model}

In general, the SBM-DEA model can be divided into two categories: input-oriented model and output-oriented model. A suitable model is useful in guiding production and operation activities, and inputs are easier to control compared to outputs. Therefore, this paper adopts an input-oriented DEA model and analyzes the collected data through DEAP 2.1 (Table 2).

Table 2. Result of SBM-DEA Model.

\begin{tabular}{ccccc}
\hline Decision Unit & $\mathbf{2 0 1 5}$ & $\mathbf{2 0 1 6}$ & $\mathbf{2 0 1 7}$ & $\mathbf{2 0 1 8}$ \\
\hline China Overaseas Land & 1.000 & 1.000 & 1.000 & 1.000 \\
China Resources Land & 0.442 & 0.537 & 0.461 & 0.563 \\
China Evergrand & 0.339 & 0.463 & 0.590 & 0.604 \\
Biguiyuan & 0.580 & 0.772 & 0.805 & 1.000 \\
SHOUKAI & 1.000 & 1.000 & 1.000 & 1.000 \\
LONGFOR & 0.346 & 0.334 & 0.333 & 0.414 \\
Shimao Real Estate & 1.000 & 1.000 & 1.000 & 1.000 \\
Merchants Shekou & 0.632 & 0.602 & 0.680 & 0.686 \\
Landsea & 0.817 & 0.946 & 1.000 & 1.000 \\
VANKE & 1.000 & 1.000 & 1.000 & 1.000 \\
YUEXIU PROPERTY & 0.654 & 0.676 & 1.000 & 1.000 \\
SINO-OCEAN & 0.652 & 0.809 & 0.950 & 1.000 \\
JINKE & 0.337 & 0.496 & 0.349 & 0.473 \\
FINANCIAL STREET HOLDINGS & 1.000 & 1.000 & 1.000 & 1.000 \\
GREEN LAND & 1.000 & 1.000 & 1.000 & 1.000 \\
Mean & 0.701 & 0.776 & 0.811 & 0.849 \\
\hline
\end{tabular}

The result of cluster analysis on the average value of the SBM efficiency of 15 companies in three years with SPSS21 has been shown in the following Table 3.

Table 3. Cluster Result.

\begin{tabular}{cccc}
\hline Cluster Type & Cluster Item & Cluster Center & Case Number \\
\hline 1 & China Overseas Land, SHOUKAI, VANKE, & & 7 \\
& FINANCIAL STREET HOLDINGS, GREEN LAND, & 0.90 & \\
Shimao Real Estate, landsea & & 5 \\
3 & China Evergrande, Biguiyuan, Merchants Shekou, & 0.62 & 3 \\
\hline
\end{tabular}

From 2013 to 2015, the green production efficiency of seven companies-China Overseas Land, SHOUKAI, VANKE, FINANCIAL STREET HOLDINGS, GREEN LAND, Shimao Real Estate, landsea-is on the top level; three companies-LONGFOR, China Resources Land, JINKE- experience the lowest green production efficiency; the green production efficiency of the other five companies-China Evergrande, Biguiyuan, Merchants Shekou, YUEXIU PROPERTY, SINO-OCEAN GROUP—is in the middle. 
It can be seen from Table 2 that green production efficiency has been rising, indicating that real estate companies have strengthened the control over $\mathrm{CO}_{2}$ emissions and their input-output has efficiency increased. As for scale returns, there are few changes in the number of companies with decreasing scale returns. Most companies are in the stage of constant returns to scale, indicating a relatively stable production level.

At the micro level, Table 2 shows that five companies, SHOUKAI, VANKE, FINANCIAL STREET HOLDINGS, GREEN LAND and Shimao Real Estate, have top-level eco-environmental efficiency for three consecutive years, which indicates that their work on production, energy conservation and emission reduction has been effective; China Overseas Land and Shimao Real Estate have fronted in overall efficiency and scale efficiency for two consecutive years. Although the efficiency value of these two companies has not reached the highest in one year, the values of overall efficiency and eco-environmental efficiency are high, indicating that these companies have better performance in balancing efficient production, energy conservation and emission reduction. There is a upward trend in various efficiency values of most enterprises, indicating that companies have realized energy conservation, emission reduction and productivity increase through the improvement of production factors such as technology and human resources. Companies such as China Resources Land and JINKE have lower production efficiency; the reason lies in their input redundancy and output insufficiency.

\subsection{Malmquist Dynamic Efficiency Evaluation}

The Malmquist productivity index is employed to analyze the change of green total factor productivity (TFP) from 2015 to 2018. From 2015 to 2018, the average TFP of Chinese real estate enterprises in each stage was greater than 1 , which indicates that the overall production efficiency of Chinese real estate enterprises is on the rise. The increasing average TFP from 1.002 to 1.076 indicates that the improvement rate of the overall efficiency of the industry is accelerating (see Table 4).

Table 4. Value of Total Factor productivity.

\begin{tabular}{cccc}
\hline Decision Unit & 2015-2016 & $\begin{array}{c}\text { Tfpch } \\
\text { 2016-2017 }\end{array}$ & 2017-2018 \\
\hline China Overaseas Land & 0.755 & 0.989 & 0.973 \\
China Resources Land & 1.040 & 1.103 & 1.479 \\
China Evergrand & 0.513 & 0.928 & 1.107 \\
Biguiyuan & 1.031 & 0.772 & 0.874 \\
SHOUKAI & 0.881 & 0.946 & 1.054 \\
LONGFOR & 1.357 & 1.095 & 0.726 \\
Shimao Real Estate & 0.791 & 0.925 & 1.272 \\
Merchants Shekou & 1.341 & 1.037 & 0.766 \\
Landsea & 0.611 & 0.866 & 1.147 \\
VANKE & 1.156 & 1.449 & 1.160 \\
YUEXIU PROPERTY & 1.188 & 1.256 & 0.810 \\
SINO-OCEAN GROUP & 1.170 & 0.861 & 1.384 \\
JINKE & 0.873 & 0.825 & 1.223 \\
FINANCIAL STREET HOLDINGS & 1.293 & 1.150 & 1.000 \\
GREEN LAND & 1.026 & 0.987 & 1.179 \\
Mean & 1.002 & 1.013 & 1.076 \\
\hline
\end{tabular}

Table 5 shows the result of TFP decomposition, which is able to explain why TFP changes. The technical efficiency of Chinese real estate companies from 2015 to 2016 and from 2016 to 2017 decreased by $1.2 \%$ and $0.2 \%$, respectively. However, an upward trend of the green total factor productivity was shown. From the data in the table, we can see that technology progress is the reason that the green factor productivity increased. The improvement rate of technology progress was $4 \%$ and $2.3 \%$ respectively in these two periods. 
Table 5. Index Decomposition Value.

\begin{tabular}{|c|c|c|c|c|c|c|}
\hline \multirow{2}{*}{ Decision Unit } & \multicolumn{3}{|c|}{ Effch } & \multicolumn{3}{|c|}{ Techch } \\
\hline & 2015-2016 & 2016-2017 & 2017-2018 & 2015-2016 & 2016-2017 & 2017-2018 \\
\hline China Overaseas Land & 1.000 & 1.000 & 1.000 & 0.755 & 0.989 & 0.973 \\
\hline China Resources Land & 1.356 & 1.310 & 1.398 & 0.767 & 0.842 & 1.058 \\
\hline China Evergrand & 0.801 & 0.784 & 1.000 & 0.640 & 1.184 & 1.107 \\
\hline Biguiyuan & 1.116 & 1.002 & 1.000 & 0.924 & 0.770 & 0.874 \\
\hline SHOUKAI & 1.000 & 1.000 & 1.000 & 0.881 & 0.946 & 1.054 \\
\hline LONGFOR & 0.733 & 1.118 & 1.092 & 1.850 & 0.979 & 0.665 \\
\hline Shimao Real Estate & 1.000 & 1.000 & 1.000 & 0.791 & 0.925 & 1.272 \\
\hline Merchants Shekou & 1.027 & 0.990 & 1.505 & 1.306 & 1.047 & 0.509 \\
\hline Landsea & 1.000 & 1.000 & 1.000 & 0.611 & 0.866 & 1.147 \\
\hline VANKE & 1.000 & 1.000 & 1.000 & 1.156 & 1.449 & 1.160 \\
\hline YUEXIU PROPERTY & 1.165 & 1.063 & 1.549 & 1.019 & 1.182 & 0.523 \\
\hline SINO-OCEAN GROUP & 1.000 & 1.000 & 1.000 & 1.170 & 0.861 & 1.384 \\
\hline JINKE & 0.616 & 0.708 & 1.000 & 1.418 & 1.165 & 1.223 \\
\hline FINANCIAL STREET HOLDINGS & 1.000 & 1.000 & 1.000 & 1.293 & 1.150 & 1.000 \\
\hline GREEN LAND & 1.000 & 1.000 & 1.000 & 1.026 & 0.987 & 1.179 \\
\hline Mean & 0.988 & 0.998 & 1.102 & 1.040 & 1.023 & 1.009 \\
\hline
\end{tabular}

Notes: effch is technical efficiency, techch is technology progress.

The data in Table 6 show that the technical efficiency value of thirteen companies has reached one, while only nine of them have their green total factor productivity index exceed one. These enterprises with green total factor productivity index less than 1 have not improved their technology promptly, therefore their energy conservation and emission reduction have lower efficiency, which affected their green total factor productivity negatively. The TFP index of most companies exceeds 1 , indicating that technological progress has increased their productivity, while saving energy and reducing emissions. Other enterprises should learn advanced technology and the experience of these enterprises to improve eco-environmental protection efficiency and energy utilization efficiency.

Table 6. The mean value of Malmquist index and its decomposition term.

\begin{tabular}{cccccc}
\hline Decision Unit & Effch & Techch & Pech & Sech & Tfpch \\
\hline China Overaseas Land & 1.000 & 0.906 & 1.000 & 1.000 & 1.046 \\
China Resources Land & 1.355 & 0.889 & 1.349 & 1.008 & 1.207 \\
China Evergrand & 1.017 & 0.977 & 0.946 & 0.908 & 0.849 \\
Biguiyuan & 1.039 & 0.856 & 1.000 & 1.039 & 0.892 \\
SHOUKAI & 1.000 & 0.960 & 1.000 & 1.000 & 0.960 \\
LONGFOR & 0.981 & 1.165 & 0.951 & 1.040 & 1.059 \\
Shimao Real Estate & 1.000 & 0.996 & 1.000 & 1.000 & 0.996 \\
Merchants Shekou & 1.174 & 0.954 & 1.134 & 1.041 & 1.048 \\
Landsea & 1.000 & 0.875 & 1.000 & 1.000 & 0.875 \\
VANKE & 1.000 & 1.255 & 1.000 & 1.000 & 1.255 \\
YUEXIU PROPERTY & 1.259 & 0.908 & 1.052 & 1.207 & 1.085 \\
SINO-OCEAN GROUP & 1.000 & 1.138 & 1.000 & 1.000 & 1.138 \\
JINKE & 0.775 & 1.269 & 1.000 & 0.775 & 0.974 \\
FINANCIAL STREET HOLDINGS & 1.000 & 1.148 & 1.000 & 1.000 & 1.148 \\
GREEN LAND & 1.000 & 1.064 & 1.000 & 1.000 & 1.064 \\
Mean & 1.040 & 1.024 & 1.029 & 1.001 & 1.039 \\
\hline
\end{tabular}

Notes: effch is technical efficiency, techch is technology progress, pech is pure technical efficiency, and sech is scale efficiency; tfpch is total factor productivity; tfpch $=$ effch $\times$ techch $=$ pech $\times \operatorname{sech} \times$ techch. 


\subsection{Result Analysis of Tobit Regression}

\subsubsection{Index Selection of Tobit Model}

Apart from inputs and outputs, some other factors also affect the total factor productivity and eco-environmental efficiency of real estate companies; some factors cannot be directly quantified, and besides, problems such as data availability and the correlation between explanatory variables cannot be ignored. Therefore, this paper constructs the Tobit model with independent variables coming from several indicators of PRIMB proposed by Huang Junpeng and used to evaluate the green development competitiveness of real estate companies [57]; the dependent variable is the green production efficiency of the enterprise estimated from the SBM model. The indepenent variables are policy compliance indicator- $-\mathrm{P}$, environmental responsibility commitment indicator- $\mathrm{R}$, green innovation capability indicator- $\mathrm{I}$, indicator of green development information disclosure- $-\mathrm{M}$, and indicator of market benefit-B.

(1) P-Policy compliance indicator. In order to check whether real estate companies adopted a green development pattern and a sustainable development strategy, this paper calculates the certified construction area of green building. The equation is as follows:

$$
P=K \times\left(\frac{a_{1}}{A}+k 1 \frac{a_{2}}{A}+k 2 \frac{a_{3}}{a_{1}+a_{2}}\right)
$$

of which $K$ is the coefficient of a company's sales scale; $K$ has a following calculation equation $K=\frac{X-\min }{\max -\min }, X$ is the company's sales in a particular year, min is the lowest sales value of all companies researched in that year, and max is the highest sales value.

$A$ is the total construction area developed by a company in that year (Unit: $\mathrm{m}^{2}$ ).

$a_{1}$ is construction area of a company that has a green building evaluation mark and declared in China (Unit: $\mathrm{m}^{2}$ ).

$a_{2}$ is green construction area certified by other green certification systems in that year (Unit: $\mathrm{m}^{2}$ ).

$a_{3}$ is the high-level green construction area certified by a company in that year, including two-star and three-star green construction area with China Evaluation Mark and green construction area, with gold and platinum international construction evaluation marks.

$k_{1}$ is the difference correction coefficient of the green building evaluation system. Different certification systems have different requirements on buildings and the difference should be corrected by difference correction coefficient. The coefficient is valued between zero and one, with a larger value indicating greater difference. In recent years, China's evaluation standards on green constructions have gradually improved. The differences between domestic evaluation standards and international standards have narrowed. Therefore, the value of $\mathrm{k} 1$ in this paper is fixed to be 0.2 .

$k_{2}$, the correction coefficient of high-level certification, is used to correct the proportion of the high-level green construction area. The value of $k_{2}$ is 0.1 in this paper.

(2) $\mathrm{R}$-Environmental responsibility commitment indicator. Apart from obeying the most basic policies, real estate companies also have the responsibility to proactively disclose information and data on energy consumption and carbon emissions. The calculation of the $\mathrm{R}$ indicator is as follows:

$$
R=\frac{1}{8} \sum_{i=1}^{6} r_{i}
$$

$r_{1}$ tells whether the corporate responsibility report discloses carbon emissions of operating revenue (unit: ton per ten thousand RMB) or the comprehensive energy consumption of the operating revenue (unit: tons of standard coal per ten thousand RMB). If the company has reported the information, $r_{1}$ takes the value of 0.6 , otherwise the value is zero. 
$r_{2}$ measures whether the social responsibility report releases information on carbon emission degree of self-sustained property (unit: ton per year). If the company has reported the information, $r_{2}$ takes the value of 0.4 , otherwise zero.

$r_{3}$ checks whether the social responsibility report has information on the overall plan, management strategy and achievements of companies' green development. If the report has such information, $r_{3}$ takes the value of 1 , otherwise zero.

$r_{4}$ distinguishes whether the company joins the green supply chain plan. If the answer is yes, the value is one, otherwise zero.

$r_{5}$ measures whether the company actively participates in activities and international communications related to the development of green constructions. If it participates, the value of $r_{5}$ is 0.6 , otherwise zero.

$r_{6}$ tells whether the company is a member of industry organizations that are related to green development, such as associations and committees. If it participates, the value of $r_{6}$ is 0.4 , otherwise zero.

(3) I-Green innovation capability indicator. This indicator measures the intensity of enterprises' scientific research and innovation in green development. The real estate industry is a capital-intensive industry, in which technological progress can improve its development effectively and promote the realization of sustainable development goals. The development of scientific research and innovation is capable of finding companies in the real estate industry; a development path with improving ecological environment. The calculation formula is as follows:

$$
I=\frac{\frac{i_{1}}{I_{1}}+\frac{i_{2}}{I_{2}}}{2}
$$

of which $i_{1}$ represents the funding invested by the company and used on green technology research in that year, $I_{1}$ is the annual operating income, $i_{2}$ is the number of scientific researchers, and $I_{2}$ is the number of employees.

(4) M-Indicator of green development information disclosure. This indicator is used to measure the information disclosure degree of the company's green development. The equation is as follows:

$$
M=\frac{n_{1}-n_{3}+\frac{1}{5} n_{2}}{100}
$$

$n_{1}$ represents the number of green development items disclosed by the company in the media or magazines.

$n_{2}$ is the number of green development items released by the company on its official website.

$n_{3}$ is the number of negative messages related to green development.

(5) Indicator of market benefit-B: this paper selects the debt asset ratio as an indicator of market benefit, which can reflect the debt payment ability of an enterprise. This indicator measures the ability of the company to conduct operating activities with funds provided by creditors, and this is also the indicator which is used to reflect the security degree when creditors give out loans. It is obtained by comparing the total debt of the enterprise with the total assets, and reflects the debt ratio of the enterprise. The reasonable use of borrowed funds can improve the flexibility of business operations, thereby improving the productivity of enterprises.

Based on the above assumptions, the TOBIT models on the company's overall efficiency and on the company's efficiency of the ecological environment are set to be:

$$
S B M_{i t}=\beta_{0}+\beta_{1} \times \ln P_{i t}+\beta_{2} \times \ln R_{i t}+\beta_{3} \times \ln I_{i t}+\beta_{4} \times \ln M_{i t}+\beta 5 \ln B_{i t}+\zeta
$$

of which $\beta_{0}$ is the intercept, $\beta_{1}, \beta_{2}, \beta_{3}, \beta_{4}, \beta_{5}$ is the coefficient of variables, $\ln P, \ln R, \ln I, \ln M$ and $\ln B$ are logarithm form of explanatory variable $P, R, I, M$ and $B$ respectively, $i$ is the number of enterprises $(i=1,2 \ldots, 15)$, and $t$ represents the year $(t=1,2,3,4), \zeta$ is the error; $S B M_{i t}$ is the value of green production efficiency of the $i$-th enterprise in year $t$. 


\subsubsection{Regression Result Analysis of Tobit Regression}

Panel data are taken to investigate the influencing factors. In order to avoid spurious variable regression, this paper checks multicollinearity with variance inflation factor (VIF). The result shows that multicollinearity has no significant influence (VIF is smaller than ten).

Tobit regression is conducted with STATA12.0. The empirical results show that the policy compliance indicator $\mathrm{P}$, environmental responsibility commitment indicator $\mathrm{R}$ and green innovation capability indicator I all have a significant positive impact on the green productivity of real estate companies. A positive but non-significant influence of the indicator of green development information disclosure $\mathrm{M}$ has also been found. The author also found that the debt asset ratio, as the indicator of market benefit, has a negative and significant impact on the green productivity (see Table 7).

Table 7. Regression Results.

\begin{tabular}{cccccc}
\hline $\begin{array}{c}\text { Dependent } \\
\text { Variables }\end{array}$ & $\begin{array}{c}\text { Independent } \\
\text { Variables }\end{array}$ & $\begin{array}{c}\text { The Estimated } \\
\text { Coefficient }\end{array}$ & $\begin{array}{c}\text { Standard } \\
\text { Error }\end{array}$ & $\boldsymbol{t}$ Value & $\boldsymbol{P}>|\boldsymbol{t}|$ \\
\hline \multirow{4}{*}{ Green } & Indicator-P & 0.559099 & 1.725232 & 3.34 & $0.002^{* * *}$ \\
Productivity & Indicator-R & 0.311862 & 0.612806 & 1.81 & $0.077^{*}$ \\
& Indicator-I & 0.6368389 & 0.0510514 & 2.68 & $0.011^{* *}$ \\
& Indicator-M & 0.102813 & 0.0542682 & 0.56 & 0.580 \\
& Indicator-B & -0.1736589 & 0.754279 & 1.53 & $0.035^{* *}$ \\
\hline
\end{tabular}

Note: ${ }^{*}$ significant at $10 \%$; ${ }^{* *}$ significant at $5 \%$; ${ }^{* * *}$ significant at $1 \%$.

The positive effect of the policy compliance indicator $p$ on the improvement of green productivity of real estate companies is significant. A one percentage increase in this indicator is coupled with a 0.559 percentage growth in the green productivity of real estate companies. It can be inferred that the productivity of real estate companies will be increased when these companies' developments follow the green development regulations of the nation. Besides, the higher the proportion of green construction area and the total sales is, the higher the value of the indicator and the productivity. This result is in line with the concept of green development.

A positive relationship is also found between environmental responsibility commitment indicator $\mathrm{R}$ and the green productivity of real estate companies. When the value of $\mathrm{R}$ increases by $1 \%$, the green productivity will increase by $0.312 \%$. This indicates that the proactive disclosure of energy consumption results in the improvement of green productivity. The reason could be that an enterprise which actively discloses its carbon emission is more likely to be active in green development; also it is more willing to be supervised and its green development will be carried more efficiently.

As for the green innovation capability indicator, this factor has the largest impact on green productivity. A one percentage increase in the green innovation capability is accompanied with a 0.637 percentage growth in green productivity. The positive and significant between this indicator and the green productivity implies that the increase in green productivity depends largely on the improvement of research funds and human resources input.

Compared to other factors, the impact of green development information disclosure on green productivity is positive, but not significant. The information on green development disclosed by companies can only be served as references, since its effect on green productivity is limited and non-significant.

Finally, the asset-liability ratio affects green productivity negatively. The increase of debts will bring companies more production risks and these companies will face problems, such as insufficient cash flow. The investment on production, energy conservation and environment protection will be reduced when these problems exist, and finally, green productivity is affected negatively too.

\section{Conclusion and Discussion}

In this paper, the author first analyzes the static productivity of Chinese real estate companies with the SBM-DEA model, and then investigates the evolution of green total factor productivity with 
the Malmquist productivity index. Besides, the author also explores the influencing factors of green productivity with Tobit models.

The results show that Chinese real estate companies have developed very well, with green productivity taking a value bigger than 0.7 and the overall productivity of these companies being very high. This is consistent with previous research [24-26]. The green productivity of five companies, China Overseas Land, SHOUKAI, VANKE, FINANCIAL STREET HOLDINGS and GREEN LAND, takes the value of 1 , indicating that they have maintained high productivity while reducing energy consumption and carbon emissions. In contrast, LONGFOR, CR land and JINKE experienced low productivity. They have the problem of input redundancy; in order to increase their green productivity and achieve sustainable development, they have to advance their technology in production.

After the green productivity of each company is calculated, these total factor productivities are analyzed dynamically with the Malmquist index. From 2015 to 2018, the average value of green total factor productivity of enterprises in all stages is greater than 1 , indicating that the average productivity of enterprises is constantly improving, which is consistent with the results of the SBM-DEA model evaluation. The green total factor productivity index of most companies is greater than 1 , indicating that these companies have been improving their production technology and reducing their energy consumption. However, some companies have lowered their green total factor productivity, due to their low value of technological progress. This finding is consistent with the previous research conclusions of Y. Wang [58]. These companies need to increase research investment, adopt advanced production technology and learn great production experience from other companies, so that they could increase their green production efficiency and strengthen their competitiveness.

In order to further analyze the factors that may affect the green production efficiency of enterprises, Tobit models are used in regression, and some indicators in the PRIMB are modified and adopted as explanatory variables. Through empirical analysis, we find that five indicators have a significant positive impact on the green productivity of real estate companies. They are the policy compliance indicator $\mathrm{P}$, environmental responsibility commitment indicator R, green innovation capability indicator I, and the indicator of green development information disclosure $\mathrm{M}$; however, the asset-liability ratio as the indicator of market benefit has a negative impact on the green productivity. As the proportion of $\mathrm{R} \& \mathrm{D}$ personnel and green production efficiency show a highly positive correlation, technological progress is the key factor affecting productivity, which is consistent with the results of the TFP decomposition. After analyzing the results of three models, this paper evaluates the static green productivity of Chinese real estate companies, describes the development trend of these companies and investigates the influencing factors of their green productivities. The author offers suggestions and advices to senior managers in making decisions and in improving the green productivities of Chinese real estate companies.

First, companies should pay attention to the improvement of pure technical efficiency and optimize the production process to reduce energy consumption and $\mathrm{CO}_{2}$ emissions. Second, more funds and researchers should be invested and cultivated, so that companies can improve their green productivity, realize the green development of high production efficiency and low energy consumption, and thereby increase general productivity. At last, companies also need to take the responsibility of releasing green development information and adopt a sustainable development path.

Author Contributions: Z.Y. proposed the original concept and methods, and finished the first draft. H.F. supervised the manuscript. All authors have read and agreed to the published version of the manuscript.

Funding: This research was funded by the Research Project on Major Issues in the Philosophy and Social Science Research of the Ministry of Education (grant number 17JZD023); National Natural Science Foundation of China (grant number 71773006).

Conflicts of Interest: The authors declare no conflict of interest.

\section{References}

1. IPCC. Climate Change 2007: The Physical Science Basis; Intergovernmental Panel on Climate Change: Geneva, Switzerland, 2007. 
2. United Nations Framework Convention on Climate Change. Adoption of the Paris Agreement [EB/OL]. Available online: http://unfccc.int/paris_agreement/items/9485.php (accessed on 1 June 2019).

3. National Bureau of Statistics of China. China Statistical Yearbook; China Statistics Press: Beijing, China, 2017.

4. Zhang, Y.J.; Da, Y.B. The decomposition of energy-related carbon emission and its decoupling with economic growth in China. J. Renew. Sustain. Energy Rev. 2015, 41, 1255-1266. [CrossRef]

5. Lewis, A. Economic Development with Unlimited Supplies of Labor. Manch. Sch. 1954, 22, $139-191$. [CrossRef]

6. Solow, R.M. Technical Change and the Aggregate Production Function. Rev. Econ. Stat. 1957, 39, $312-320$. [CrossRef]

7. Denison, E.F. Accounting for United States Economic Growth, 1929-1969; Brookings Institution: Washington, DC, USA, 1974.

8. Kang, D.; Lee, D.H. Energy and environment efficiency of industry and its productivity effect. J. Clean. Prod. 2016, 135, 184-193. [CrossRef]

9. Lin, B.; Long, H. A stochastic frontier analysis of energy efficiency of China's chemical industry. J. Clean. Prod. 2015, 87, 235-244. [CrossRef]

10. Song, M.L.; Zhou, Y.X. Analysis of carbon emissions and their influence factors based on data from Anhui of China. Comput. Econ. 2015, 46, 359-374. [CrossRef]

11. Yu, C.; Li, H.; Jia, X.; Li, Q. Improving resource utilization efficiency in China's mineral resource-based cities: A case study of Chengde Hebei province. Resour. Conserv. Recycl. 2015, 94, 1-10. [CrossRef]

12. Zeng, S.; Chen, X.; Dong, X.; Liu, Y. Efficiency assessment of urban wastewater treatment plants in China: Considering greenhouse gas emissions. Resour. Conserv. Recycl. 2017, 120, 157-165. [CrossRef]

13. Bian, Y.; Yan, S.; Xu, H. Efficiency evaluation for regional urban water use and wastewater decontamination systems in China: A DEA approach. Resour. Conserv. Recycl. 2014, 83, 15-23. [CrossRef]

14. Hu, J.L.; Wang, S.C. Total-factor energy efficiency of regions in China. Energy Policy 2006, 34, 3206-3217. [CrossRef]

15. Lozano, S.; Iribarren, D.; Moreira, M.T.; Feijoo, G. Environmental impact efficiency in mussel cultivation. Resour. Conserv. Recycl. 2010, 54, 1269-1277. [CrossRef]

16. Shi, G.M.; Bi, J.; Wang, J.N. Chinese regional industrial energy efficiency evaluation based on a DEA model of fixing non-energy inputs. Energy Policy 2010, 38, 6172-6179. [CrossRef]

17. Han, S.S.; George, O. Construction industry in China's regional economy, 1990-1998. Constr. Manag. Econ. 2001, 19, 189-205. [CrossRef]

18. Li, X.D.; Shen, G.Q.; Xue, X.L. Application of DEA-Based Malmquist Productivity Index Measure to the Construction Industry in China. J. Constr. Res. Congr. 2005, 852, 617-626.

19. Xue, X.; Shen, Q.; Wang, Y.; Lu, J. Measuring the Productivity of the Construction Industry in China by Using DEA-Based Malmquist Productivity Indices. J. Constr. Eng. Manag. 2008, 134, 64-71. [CrossRef]

20. Zhao, N.X.; Li, C. Efficiency research of real estate in China. J. Mod. Econ. Inf. 2011, 16, 274-275.

21. Zheng, J.J.; Han, X.; Pan, Z.Y. Analysis on TFP growth and convergence in real estate development companies based on Malmquist index method. J. China Soft Sci. 2013, 3, 141-151.

22. Jan, J. Construction Site Productivity Measurement: Selection, Application and Evaluation of University of Methods and Measures. Vet. Anaesth. Analg. 1996, 38, 413-414.

23. Nguyen, K.M.; Giang, T.L. Efficiency of Construction Firms in Vietnam. In Technical Efficiency and Productivity Growth in Vietnam: Parametric and Non-parametric Analyses; Nguyen, K.M., Giang, T.L., Eds.; National Economics University: Hanoi, Vietnam, 2007; pp. 44-59.

24. Liu, Y.L.; Sun, Z.M. Evaluation of the efficiency of listed real estate companies by DEA. J. Stat. Inf. Forum 2006, 21, 74-78.

25. Yuan, F.; Gao, Y. Evaluation and optimization analysis of the efficiency of real estate industry in China-based on 20 Chinese listed real estate companies from 2000 to 2007. J. Mod. Bus. 2009, 14, 60-62.

26. Ren, F.; Qian, Z. Empirical research on efficiency measurement of real estate companies. J. Constr. Econ. 2009, 2, 110-114.

27. Lu, J.C.; Zuo, X.F. Analyze the efficiency and its influencing factors of China's listed real estate companies based on super-efficiency DEA-Tobit model. J. Luojia Manag. Rev. 2010, 2, 156-162.

28. Wang, J.Q.; Yang, J.J. Analysis on dynamic investment efficiency in real estate enterprises: Based on the Malmquist index approach. J. Contemp. Econ. Manag. 2010, 32, 84-88. 
29. Pittman, R.W. Multilateral comparisons with undesirable outputs. J. Econ. 1983, 93, 883-891. [CrossRef]

30. Chung, Y.H.; Fare, R.; Grosskopf, S. Productivity and undesirable outputs: A directional distance function approach. J. Environ. Manag. 1997, 51, 229-240. [CrossRef]

31. Fare, R.; Grosskopf, S., Jr.; Pasurka, C.A. Accounting for air pollution emissions in measures of state manufacturing productivity growth. J. Reg. Sci. 2001, 41, 381-409. [CrossRef]

32. Tone, A. Slacks-Based measure of efficiency in data envelopement analysis. Eur. J. Oper. Res. 2001, 130, 498-509. [CrossRef]

33. Li, J.; Chiang, Y.H.; Choi, T.N.Y.; Man, K.F. Determinants of efficiency of contractors in Hong Kong and China: Panel data model analysis. J. Constr. Eng. Manag. 2013, 139, 1211-1223. [CrossRef]

34. Xue, X.L.; Wu, H.Q.; Zhang, X.L.; Jason, D.; Su, C. Measuring energy consumption efficiency of the construction industry: The case of China. J. Clean. Prod. 2015, 107, 509-515. [CrossRef]

35. Liu, H.X.; Lin, B.Q. Energy substitution, efficiency, and the effects of carbon taxation: Evidence from China's building construction industry. J. Clean. Prod. 2017, 141, 1134-1144. [CrossRef]

36. Wu, Y.; Lu, W.S.; Chen, J.D. Decoupling relationship between economic output and carbon emission in the Chinese construction industry. J. Environ. Impact Assess. Rev. 2018, 71, 60-69. [CrossRef]

37. Hu, X.C.; Liu, C.L. Managing undesirable outputs in the Australian construction industry using Data Envelopment Analysis models. J. Clean. Prod. 2015, 101, 148-157. [CrossRef]

38. Lee, P.; Wang, M.C.; Chan, E.H.W. An analysis of problems with current indicators for evaluating carbon performance in the construction industry. Procedia Eng. 2016, 164, 25-28. [CrossRef]

39. Castro-Lacouture, D.; Sefair, J.A.; Flórez, L.; Medaglia, A.L. Optimization model for the selection of materials using a LEED-based green building rating system in Colombia. Build. Environ. 2009, 44, 1162-1170. [CrossRef]

40. Chang, N.B.; Rivera, B.J.; Wanielista, M.P. Optimal design for water conservation and energy savings using green roofs in a green building under mixed uncertainties. J. Clean. Prod. 2011, 19, 1180-1188. [CrossRef]

41. Zhang, J. Application of green building technologies in commercial buildings. Door Window 2013, 8, 125.

42. Bingöl, E.; Kılkış, B.; Eralp, C. Exergy based performance analysis of high efficiency poly-generation systems for sustainable building applications. Energy Build. 2011, 43, 3074-3081. [CrossRef]

43. Wang, N.; Chang, Y.C.; Nunn, C. Lifecycle assessment for sustainable design options of a commercial building in Shanghai. Build. Environ. 2010, 45, 1415-1421. [CrossRef]

44. Ding, G.K.C. Sustainable construction-The role of environmental assessment tools. J. Environ. Manag. 2008, 86, 451-464. [CrossRef]

45. Stoebaro, V.L.; Williamson, T.J. Multi-criteria assessment of building performance: Theory and implementation. Build. Environ. 2001, 36, 681-690.

46. Coimbra, J.; Almeida, M. Challenges and benefits of building sustainable cooperative housing. Build. Environ. 2013, 62, 9-17. [CrossRef]

47. Bartlett, E.; Howard, N. Informing the decision-makers on the cost and value of green building. Build. Res. Inf. 2000, 28, 315-324. [CrossRef]

48. Lam, P.T.I.; Chan, E.H.W.; Chau, C.K.; Poon, C.S.; Chun, K.P. Integrating green specifications in construction and overcoming barriers in their use. J. Prof. Issues Eng. Educ. Pract. 2009, 135, 142-152. [CrossRef]

49. Waddel, H. Sustainable construction and UK legislation and policy. Manag. Procure. Law 2008, 161, $127-132$. [CrossRef]

50. Verrier, B.; Rose, B.; Caillaud, E.; Remita, H. Combining organizational performance with sustainable development issues: The Lean and Green project benchmarking repository. J. Clean. Prod. 2014, 85, 83-93. [CrossRef]

51. Juan, Y.K.; Gao, P.; Wang, J. A hybrid decision support system for sustainable office building renovation and energy performance improvement. Energy Build. 2010, 42, 290-297. [CrossRef]

52. Espinoza, O.; Buehlmann, U.; Smith, B. Forest certification and green building standards: Overview and use in the US hardwood industry. J. Clean. Prod. 2012, 33, 30-41. [CrossRef]

53. Charnes, A.; Cooper, W.W.; Rhodes, E. Measuring the efficiency of decision making units. Eur. J. Oper. Res. 1978, 2, 429-444. [CrossRef]

54. Färe, R.; Grosskopf, S.; Linderdgren, B. Productivity changes in Swedish pharmacies 1980-1989: A nonparametric Malmquist approach. J. Product. Anal. 1992, 3, 85-101. [CrossRef] 
55. Färe, R.; Grosskopf, S.; Norris, M. Productivity growth, technical progress, and efficiency change in industrialized countries. J. Am. Econ. Rev. 1994, 84, 66-83.

56. Tobin, J. Estimation of relationships for limited dependent variables. J. Econom. 1958, 26, 24-36. [CrossRef]

57. Huang, J.; Wang, Y. Research on the Green Development Evaluation Index of Chinese Real Estate Enterprises. J. Constr. Sci. Technol. 2017, 23, 39-44.

58. Wang, Y.; Zhu, Y.; Jiang, M. Efficiency evaluation of listed real estate companies in China. In The Strategies of China's Firms; Yang, H., Morgan, S.L., Wang, Y., Eds.; Chandos Publishing: Oxford, England, 2015; pp. 89-107. 